\title{
ZMIANY TRANSGRANICZNEGO RUCHU TURYSTYCZNEGO NA POGRANICZU POLSKO-BIAtORUSKIM NA PRZYKŁADZIE KANAŁU AUGUSTOWSKIEGO
}

\author{
Aliaksandr Cyargeenkaa \\ ${ }^{a}$ Instytut Geografii i Przestrzennego Zagospodarowania im. S. Leszczyckiego PAN, Zakład Geografii Miast i Ludności; \\ https://orcid.org/0000-0002-9714-4128; e-mail: aliaksandrc@twarda.pan.pl
}

\begin{abstract}
ABSTRAKT
Kanał Augustowski jest jedną z wyjątkowych atrakcji turystycznych pogranicza polsko-białoruskiego, znaną z wysokich walorów przyrodniczych, kulturowo-historycznych oraz turystycznych. Od początku XXI w., po całkowitej renowacji oraz po otwarciu zarówno rzecznego (2005 r.), jak i drogowego (2017 r.) przejścia Rudawka-Lesnaja, obserwuje się wielokrotny wzrost granicznego ruchu turystycznego w obrębie przestrzeni turystycznej Kanału Augustowskiego. Z jednej strony artykuł ma być próbą wypełnienia luki badawczej związanej z aktualną analizą struktury i dynamiki natężenia ruchu granicznego pod kątem zróżnicowania kraju pochodzenia turystów, sezonowości oraz wyboru rodzaju ruchu - rzecznego (środkiem pływającym) bądź drogowego (rowerem lub pieszo). $Z$ drugiej strony opracowanie stanowi kontynuację badania wpływu złagodzenia reżimu granicznego na Białorusi (wprowadzenie stref bezwizowych) na wielkość ruchu turystycznego. Analizę czynników oddziałujących na transgraniczny ruch turystyczny na Kanale Augustowskim wykonano na różnych poziomach - lokalnym, regionalnym, krajowym oraz międzynarodowym - za pomocą podejścia wieloskalowego (multi-scalar). Poza tym zorganizowano badania terenowe, podczas których zastosowano metodę obserwacji uczestniczącej, a także wykorzystano metodę analizy danych statystycznych, pochodzących z raportów polskiej Straży Granicznej. Wyniki badań wskazują na to, że najwięcej turystów korzystających z przejścia granicznego Rudawka-Lesnaja pochodzi z Polski i Białorusi, natomiast mniejszy udział mają podróżni z Litwy, Rosji oraz Niemiec. Polacy najczęściej wybierają możliwość rzecznego przekroczenia granicy, Białorusini zaś preferują tryb drogowy.
\end{abstract}

\section{SŁOWA KLUCZOWE}

Kanał Augustowski, ruch graniczny, strefy bezwizowe, turystyka, Polska, Białoruś

\section{INFORMACJE O ARTYKULE}

Przyjęto:

13 stycznia $2021 \mathrm{r}$.

Zaakceptowano:

11 maja $2021 \mathrm{r}$.

Opublikowano:

25 czerwca $2021 \mathrm{r}$.

Artykuł zawiera wyniki badań przeprowadzonych w ramach projektu badawczego pt. „Granice Polski jako zasoby - pomiędzy dziedzictwem a produktem turystycznym", finansowanego przez Narodowe Centrum Nauki, nr 2018/29/B/HS4/02417.

\section{WSTĘP}

Kanałem nazywany jest sztuczny ciek, rodzaj utworzonej przez człowieka śródlądowej drogi wodnej, którą stanowią skanalizowane rzeki, jeziora i nowo wybudowane odcinki cieku. Zazwyczaj kanały łączące dorzecza powodują obniżenie kosztów transportu oraz ułatwiają przewóz towarów i ludzi. Kanał Augustowski również pełni te funkcje, a dodatkowo od niedawna jest transgraniczną atrakcją turystyczną znajdującą się w obszarze wyjątkowej przyrody Puszczy Augustowskiej (Around Augustów Canal, 2018; Pogranicze..., 2018).

Kanał Augustowski jest określany przez badaczy jako pewien fenomen wśród innych pomników hydrotechnicznych głównie $z$ tego względu, że stanowi jedyną sztuczną drogę wodną na wschodniej, zewnętrznej granicy Unii Europejskiej (pogranicze Polski, Białorusi i częściowo Litwy) i tworzy swoiste przygraniczne 
kulturowo-przyrodnicze środowisko o stale rosnącym znaczeniu turystycznym (Cyargeenka, Więckowski, 2020; Marin, 2017; Sialverstava, Bogusz, Roman, 2018). Funkcjonowanie tego systemu, mającego cechy transgranicznej przestrzeni turystycznej, jest uzależnione od wielu czynników, m.in.: sieci rzek, ochrony przyrody, komunikacji transportowej, a także relacji geopolitycznych między graniczącymi ze sobą państwami (Kałuski, 2016). Jednym z warunków rozwoju funkcji turystycznej obszaru Kanału Augustowskiego jest tworzenie, promowanie oraz dywersyfikacja produktu turystycznego, bazującego na lokalnych zasobach przestrzeni, naturze, wspólnej kulturze oraz historii sąsiadujących narodów (Bogusz, Sialverstava, 2018; Kul-Sialverstava, 2014).

Obszar (hydrowęzeł) Kanału Augustowskiego przyciąga turystów przede wszystkim z Polski, Białorusi oraz Litwy. Stanowi element transgranicznej turystyki „sentymentalnej” albo „kresowej”, pełniąc funkcję kręgosłupa, wokół którego usytuowanych jest wiele obiektów dziedzictwa kulturowego (Lenart, 2008; Sialverstava, Bogusz, 2018). Ponadto obszar ten postrzegany jest jako jeden z możliwych "mostów” do transgranicznej współpracy na rzecz ochrony środowiska oraz rozwoju ekoturystyki na różnych poziomach - lokalnym, regionalnym, krajowym i międzynarodowym (Marin, 2011, 2017).

Granice państw stanowią odzwierciedlenie relacji między sąsiadami - zmieniającą się kombinację konfliktu, konkurencji, podporządkowania i współpracy, a także różne aspekty postrzegania granicy (Kolosov, Więckowski, 2018). Kanał Augustowski stanowi dobry podmiot badań ciągle zmieniających się transgranicznych procesów społeczno-ekonomicznych oraz politycznych, które są zarówno integracyjne, jak i dezintegracyjne (Cyargeenka, Więckowski, 2020; Marin, 2017). Pierwotnie, w latach 1820-1840, pełnił on funkcję arterii transportowej łączącej zachodni przygraniczny obszar Imperium Rosyjskiego z Bałtykiem, później stracił on swoje podstawowe znaczenie gospodarze, po II wojnie światowej zaś znalazł się w dwóch różnych państwach - Polsce i ZSRR. Od lat 70. XX w. po stronie polskiej, a od początku XXI w. na pograniczu polsko-białoruskim Kanał Augustowski stopniowo nabiera cech istotnego elementu przestrzeni turystycznej z dynamicznie rozwijającym się kajakarstwem oraz innymi formami turystyki aktywnej (Cudowski, Górniak, 2008).

Badania struktury oraz motywacji zwiedzających, łącznie z zagadnieniami dotyczącymi trybu przekraczania granicy, ukazują kwestie organizacyjne, finansowe oraz psychologiczne, które mogą hamować lub dynamizować frekwencję turystyczną w przestrzeni Kanału Augustowskiego (Bobowska, 2018; Yeliseyeu, 2017). Wyjątkowym zjawiskiem pod tym względem jest proces wprowadzenia oraz poszerzania przygranicznych stref bezwizowego wjazdu na Białoruś dla obywateli ok. 70 państw, który został uruchomiony w latach 2015-2016, ale w obecnym czasie napotyka wiele wyzwań (Kudžmaitè, 2019; Więckowski, Cyargeenka, 2019). W literaturze przedmiotu brakuje aktualnych badań przestrzeni Kanału Augustowskiego pod kątem okoliczności wpływających na intensyfikację oraz strukturę transgranicznego ruchu turystycznego, a także analiz opartych na pierwotnych danych statystycznych dotyczących ruchu granicznego (pojawiły się one stosunkowo niedawno). Artykuł stanowi próbę uzupełnienia tej luki badawczej.

Celem pracy jest przede wszystkim określenie czynników wpływających na zmianę struktury i dynamiki transgranicznego ruchu turystycznego na Kanale Augustowskim, na podstawie danych statystycznych z przejścia granicznego Rudawka-Lesnaja. Postawiono następującą hipotezę badawczą: otwarcie oraz poszerzenie białoruskiej strefy bezwizowej „Park turystyczno-rekreacyjny Kanał Augustowski” wraz z wprowadzeniem możliwości przekraczania granicy pieszo bądź na rowerze pozytywnie oddziałują na intensywność ruchu turystycznego, zwłaszcza obywateli Polski i Białorusi.

\section{METODY BADAŃ}

Opracowanie ma charakter zarówno opisowy, jak i analityczny. Po pierwsze przeprowadzono kwerendę aktualnej literatury, żeby określić na jej podstawie uwarunkowania kulturowo-historyczne, instytucjonalno-infrastrukturalne, formalnoprawne i in. Analizę czynników oddziałujących na transgraniczny ruch turystyczny na Kanale Augustowskim wykonano na różnych poziomach - lokalnym, regionalnym, krajowym oraz międzynarodowym - za pomocą podejścia wieloskalowego (multi-scalar) (Marin, 2011; Stoffelen, Ioannides, Vanneste, 2017).

W lipcu 2019 r. zorganizowano badania terenowe, podczas których zastosowano metodę obserwacji uczestniczącej, przekraczając granicę na przejściu granicznym Rudawka-Lesnaja pieszo i i biorąc udział w zwiedzaniu śluz Kurzyniec i Wołkuszek. Proces przekraczania granicy zawierał trzy etapy: przed, w trakcie i po (Kudžmaitè, 2019; Zichner, Beurskens, Miggelbrink, Bruns, 2017). Przed podróżą zgromadzono informacje dotyczące wizowego/bezwizowego reżimu, możliwości wypożyczenia kajaków lub rowerów, a także przygotowano niezbędne dokumenty. Podczas pobytu przed linią granicy, nie niej i poza nia, sprawdzono w terenie procedury, czas odprawy, dostępność, stan i oznakowanie infrastruktury oraz wykonano zdjęcia.

Poza tym wykorzystano metodę analizy danych statystycznych dotyczących struktury oraz dynamiki natężenia ruchu pod kątem zróżnicowania kraju 
pochodzenia turystów, sezonowości oraz preferencji rodzaju ruchu - rzecznego (środkiem pływającym) bądź drogowego (rowerem lub pieszo). Dane źródłowe pochodzą z raportów polskiej Straży Granicznej oraz dotyczą ruchu osobowego przez granicę Polski. Zastosowano selekcję oraz systematyzację całokształtu danych przejścia granicznego, kraju pochodzenia, okresu czasowego. Rezultaty uogólniono $\mathrm{w}$ formie tabel i wykresów, ukazujących najważniejsze tendencje.

\section{KANAt AUgUSTOWSKI JAKO GŁÓWNY ELEMENT PRZESTRZENI TURYSTYCZNEJ}

W artykule przeprowadzono analizę ruchu turystycznego przez przejście graniczne Rudawka-Lesnaja w kontekście przestrzeni turystycznej, z uwzględnieniem różnych poziomów (lokalnego, regionalnego, międzynarodowego). Pojęcie przestrzeni turystycznej jest różnie rozumiane zarówno przez światowych, jak i polskich badaczy. Najczęściej definiowano ją jako skutek "zachodzenia na siebie" wybranych przestrzeni geograficznych. Z opracowania Kowalczyka (2014) wynika, że przestrzeń turystyczna jest równocześnie kategorią obiektywną i subiektywną oraz że istnieją cztery postacie tradycyjnie pojmowanej przestrzeni turystycznej: przestrzeń turysty, przestrzeń turystów, przestrzeń turystyki oraz (właściwa) przestrzeń turystyczna. Problematyką delimitacji oraz klasyfikacji przestrzeni turystycznej zajmował się m.in. Włodarczyk (2014), określając przestrzeń turystyczną jako część przestrzeni geograficznej, w której występuje zjawisko ruchu turystycznego. Przestrzeń Kanału Augustowskiego ma cechy subekumeny turystycznej, która ze względu na charakter walorów (realnych, krajobrazowych, rzeczno-pojeziernych) lub zagospodarowania turystycznego (rekreacyjno-sportowego) odznacza się sezonowością, nieciągłością oraz sporadycznością ruchu turystycznego (Więckowski, 2014; Włodarczyk, 2014).

Kanał Augustowski sensu stricto jest osią wodną oraz „,kręgosłupem” łączącym dwie oddzielne (polską i białoruską) transgraniczne przestrzenie turystyczne. Szeroko rozumiany obszar Puszczy Augustowskiej (razem z Augustowem i Grodnem) stanowi przestrzeń turystyczną sensu largo. Większość Puszczy Augustowskiej razem z Kanałem Augustowskim jest położona po stronie polskiej i sąsiaduje z Wigierskim Parkiem Narodowym od północnego zachodu oraz z Biebrzańskim Parkiem Narodowym od południa. W obrębie Puszczy Augustowskiej znajdują się również cztery obszary chronionego krajobrazu (Puszcza i Jeziora Augustowskie, Dolina Rospudy, Pojezierze Sejneńskie i Dolina Biebrzy I) oraz liczne rezerwaty (Perkuć, Brzozowy Grąd itd.). Natomiast po stronie białoruskiej na obszarze Kanału Augustowskiego znajdują się: Sapoćkiński, Hożański oraz Porzeczański Rezerwat Botaniczny, park krajobrazowy Świack i krajobrazowo-przyrodniczy park w Radziwiłkach (Kopciała, 2000b; Pozlevich, 2016). Na północnym wschodzie lasy Puszczy Augustowskiej łączą się z Puszczą Kopciowską oraz Dajnawską (Litwa).

Przestrzeń turystyczna Kanału Augustowskiego jest ciekawa dla zwiedzających jako miejsce pierwotne (naturalne), ale również jako przestrzeń antropogeniczna, stworzona przez człowieka w czasach historycznych. Kanał Augustowski został zbudowany w latach 1824-1839 na ziemiach Królestwa Polskiego w obrębie ówczesnego Imperium Rosyjskiego (Romanowa, Szirokowa, Ozierowa, Czesnow, Sobisiewicz, 2018). Główną przyczyną jego powstania była wojna celna z Prusami, w wyniku której opłaty za transport polskich zbóż do Gdańska wielokrotnie wzrosły (Górewicz, Orłowski, 1973). Kanał został zaprojektowany w taki sposób, aby połączyć dorzecze Wisły z Niemnem, a także Niemen z Windawą (Kanał Windawski) i umożliwić dostęp do Bałtyku przez Inflanty.

Jedynie pierwsza część tego planu została zrealizowana. Stało się tak z kilku przyczyn. Po pierwsze, na początku prac związanych z budową Kanału Augustowskiego konieczne było obniżenie cła przez Prusy w celu uniknięcia strat (Górewicz, 1974). Po drugie, powstanie listopadowe w latach 1830-1831 zahamowało te działania (Rutkowski, 2017), potem zaś władze rosyjskie uznały pomysł budowy Kanału Windawskiego za zbędny, pozostawiając Kanałowi Augustowskiemu wyłącznie rolę transportową na lokalnym poziomie - obecnego pogranicza Polski, Białorusi oraz Litwy. Z Kanału Augustowskiego korzystano jeszcze jakiś czas głównie przy transporcie soli z Polski na Litwę i Białoruś, a potem aż do lat 70. XX w. w celu spławiania drewna. Ostatecznie szybki rozwój kolei w latach 1860-1880 zredukował transportowe oraz gospodarcze znaczenie Kanału Augustowskiego.

Przestrzeń turystyczna Kanału Augustowskiego budzi zainteresowanie turystów także pod względem dziedzictwa kulturowego, zwłaszcza hydrotechnicznego. Kanał Augustowski ma 18 śluz murowanych (21 komór) -14 w Polsce, trzy na Białorusi oraz jedną podzieloną granicą - w tym dziewięć polskich, trzy białoruskie i jedna graniczna zachowały pierwotne jądro murów z pierwszej połowy XIX w., zmieniało się tylko ich oblicowanie (Batura, 2005). Od innych podobnych obiektów Kanał Augustowski różni się dużym rozmiarem $(101 \mathrm{~km})$, obecnością wielu przekopów, jazów, zlewni oraz brakiem katastrof, jeśli chodzi o wycieki wody.

Kanał Augustowski zachował się w stanie prawie niezmienionym od czasów budowy, głównie z powodu gwałtownej redukcji jego gospodarczego znaczenia. Jest wyjątkiem na tle innych europejskich kanałów, gdyż nie podlegał modernizacji, przebudowom 
i unowocześnieniom (Górewicz, Orłowski, 1973). W 1968 r. został uznany przez polskiego ministra kultury i sztuki za zabytek sztuki inżynierskiej i architektury, w 2007 r. zaś za pomnik historii, co stało się istotnym czynnikiem rozwoju przestrzeni turystycznej. W $2010 \mathrm{r}$. złożono wniosek o wpisanie kanału na listę światowego dziedzictwa kulturowego UNESCO, ale nie przeszedł procedury weryfikacyjnej.

\section{ZMIANY FUNKCJI GRANIC I MOŻLIWOŚCI ICH PRZEKRACZANIA}

W czasach Cesarstwa Rosyjskiego Kanał Augustowski nie był podzielony granica, aczkolwiek Królestwo Polskie miało ograniczoną autonomię administracyjną. Już wtedy pojawiły się pierwsze przesłanki do rozwoju turystyki w tym miejscu. W 1909 r. została zorganizowana piesza wycieczka Polskiego Towarzystwa Krajoznawczego do Augustowa, Studzieniczej i Swobody, a w 1912 r. pieszo-wozowa "szlakiem napoleońskim” od Suwałk przez Wigry do Grodna i dalej do Bobrujska (Kopciała, 2000a).

W okresie międzywojennym Kanał Augustowski także znajdował się w obrębie jednego organizmu państwowego, co dynamizuje rozwój kajakarstwa pod patronatem harcerzy opływających Polskę dookoła. Ponadto kanałem zainteresowały się: Polski Związek Kajakowy, Oficerski Yacht Klub RP, Państwowy Zarząd Wodny, a także prywatne przedsiębiorstwa, które oferowały rejsy statkami ciągnącymi krypy z pasażerami (regularne połączenia z Augustowa oraz Grodna). Oprócz tego intensywnie rozwijała się turystyka uzdrowiskowa. Obszar Kanału Augustowskiego zaczął wówczas nabierać cech przestrzeni turystycznej.

Obszar turystyczny Kanału Augustowskiego w latach 1945-1989 został podzielony między PRL i ZSRR. Spowodowało to zanik turystyki w tym regionie z dwóch powodów - sztywnej granicy państwowej oraz poważnego zniszczenia lub uszkodzenia infrastruktury hydrotechnicznej.

Od lat 70. XX w. po stronie Polski odnotowuje się kolejny okres aktywizacji turystyki na Kanale Augustowskim, natomiast radziecka (białoruska) część została całkowicie zaniedbana. W latach 1989-2007 nastąpił okres łagodzenia trybu przekraczania granic razem ze zniesieniem reżimu wizowego. Wydarzenia z lat 2004 i 2007, czyli odpowiednio wejście Polski do Unii Europejskiej oraz przystąpienie do układu z Schengen, przyczyniły się do powstania na wschodzie zamkniętej, zewnętrznej granicy ze wzmocnioną kontrolą oraz utrudnionym trybem przekraczania w obu kierunkach (Więckowski, 2010b).

Od czasu dołączenia Polski do strefy Schengen (2007 r.) koszt wizy dla Białorusinów wynosił 60 euro.
Z dniem wejścia w życie Kodeksu Wizowego UE (2 lutego 2020 r.) cena ta wzrosła do 80 euro, jednak pół roku później (1 lipca 2020 r.) zezwolenie to kosztowało już tylko 35 euro. Co więcej, do stycznia 2019 r. istniała możliwość otrzymania tzw. wizy zakupowej (krótkoterminowej, bez dodatkowych formalności), powszechnie używanej przez Białorusinów w celach turystycznych. Dnia 22 września 2020 r. rząd Polski, po wcześniejszym zamknięciu granic pod koniec marca 2020 r. z powodu pandemii COVID-19, przywrócił możliwość wjazdu Białorusinów do kraju w celach turystycznych. Od 29 października 2020 r. wjazd z Polski na terytorium Białorusi przejściami drogowymi ponownie został wstrzymany decyzją strony białoruskiej.

Białoruska wiza dla obywateli Polski oraz innych krajów UE kosztuje w ostatnich latach od 20 do 120 euro (obecnie 35 i 75 euro) w zależności od jej typu (prywatna, służbowa, turystyczna itd.), długości pobytu, liczby wjazdów, trybu otrzymania (czas oczekiwania od 2 do 10 dni roboczych) oraz ewentualnych prowizji pobieranych przez biura podróży. Wnioski przyjmowane są w Warszawie, Białej Podlaskiej oraz Białymstoku. W latach 2007-2010 otwarty był również sezonowy punkt konsularny w Augustowie, ale został zamknięty z powodu małej liczby wydawanych wiz turystycznych.

Unikatowym zjawiskiem pod względem łagodzenia trybu przekraczania granicy stało się stopniowe wprowadzenie tzw. stref bezwizowych na Białorusi na obszarach przygranicznych z Polską i częściowo z Litwą (Więckowski, Cyargeenka, 2019). Proces ten zapoczątkowało pojawienie się w 2015 r. możliwości bezwizowego wjazdu do białoruskiej części Parku Narodowego Puszcza Białowieska na okres do 3 dób przez pieszo-rowerowe przejście Białowieża-Piererow. W przypadku Kanału Augustowskiego strefa bezwizowa w turystyczno-rekreacyjnym parku Kanał Augustowski zaczęła funkcjonować od 26 października 2016 r. na mocy Dekretu Nr 318, obejmując obszar Kanału Augustowskiego oraz miasto Grodno (tab. 1).

Przywilej bezwizowego wjazdu na przygraniczny obszar Białorusi dotyczy obywateli ok. 70 państw świata, w tym Polski, Litwy, Łotwy, Niemiec i USA. Aby móc przekroczyć granicę, niezbędne są następujące dokumenty:

- ważny paszport,

- ubezpieczenie (medyczne oraz - w przypadku podróżowania samochodem - tzw. zielona karta),

- przepustka (wystawiona przez uprawionego operatora turystycznego),

- zakup biletów wstępu do co najmniej dwóch atrakcji turystycznych,

- potwierdzenie rezerwacji miejsca noclegowego (w przypadku pobytu powyżej 10 dób).

Terytorialna spójność białoruskiej strefy bezwizowej oraz rozwijającej się przestrzeni turystycznej zachęca 
Tabela 1. Transgraniczny ruch bezwizowy w regionie Kanału Augustowskiego

\begin{tabular}{|l|l|l|l|}
\hline $\begin{array}{l}\text { Przygraniczna } \\
\text { strefa } \\
\text { bezwizowa }\end{array}$ & \multicolumn{2}{|c|}{$\begin{array}{c}\text { Park turystyczno-rekreacyjny } \\
\text { Kanał Augustowski }\end{array}$} & \multicolumn{1}{c|}{ Przestrzeń bezwizowa Brześć-Grodno } \\
\hline $\begin{array}{l}\text { Data } \\
\text { otwarcia }\end{array}$ & 26.10 .2016 & 1.01 .2018 & 10.11 .2019 \\
\hline $\begin{array}{l}\text { Długość } \\
\text { pobytu }\end{array}$ & Pobyt do 5 dób & Pobyt do 10 dób & Pobyt do 15 dób \\
\hline $\begin{array}{l}\text { Obszar } \\
\text { dostępny } \\
\text { dla ruchu } \\
\text { bezwizowego }\end{array}$ & $\begin{array}{l}\text { miasto Grodno, } \\
\text { sielsowiety: Hoża, } \\
\text { Kopciówka, Odelsk, } \\
\text { Padłabienie, } \\
\text { Sopockin z rejonu } \\
\text { grodzieńskiego }\end{array}$ & $\begin{array}{l}\text { miasto Grodno oraz } \\
\text { rejon grodzieński }\end{array}$ & $\begin{array}{l}\text { m. Grodno, rejony: grodzieński, brzestowicki, wołkowyski, } \\
\text { werenowski, lidzki, świsłocki i szczuczyński z obwodu } \\
\text { grodzieńskiego; m. Brześć, rejony: brzeski, żabinecki, } \\
\text { kamieniecki, prużański z obwodu brzeskiego }\end{array}$ \\
\hline $\begin{array}{l}\text { Przejścia } \\
\text { graniczne } \\
\text { otwierane dla } \\
\text { bezwizowego } \\
\text { ruchu }\end{array}$ & $\begin{array}{l}\text { Rudawka-Lesnaja } \\
\text { (PL-BY), Kuźnica } \\
\text { Białostocka-Bruzgi } \\
\text { (PL-BY), Privalka- } \\
\text { Svendubre (BY-LT), } \\
\text { Priwałka-Rajgardas } \\
\text { (BY-LT), }\end{array}$ & $\begin{array}{l}\text { Kuźnica Białostocka- } \\
\text { Grodno (PL-BY), Port } \\
\text { lotniczy Grodno (BY) }\end{array}$ & $\begin{array}{l}\text { Białowieża-Piererow (PL-BY), Bieniakonie-Soleczniki } \\
\text { (BY-LT), Bobrowniki-Bierestowica (PL-BY), Połowce- } \\
\text { Pieszczatka (PL-BY), Sławatycze-Domaczewo (PL-BY), } \\
\text { Terespol-Brześć (PL-BY), Terespol-Brześć (PL-BY), Port } \\
\text { lotniczy Brześć (BY) }\end{array}$ \\
\hline
\end{tabular}

Objaśnienia: BY - Białoruś, LT - Litwa, PL - Polska, RU - Rosja, UA - Ukraina.

Źródło: opracowanie własne

zwiedzających do dłuższego pobytu oraz zwiedzenia oprócz Kanału Augustowskiego również Grodna i okolic, m.in. zamku królewskiego, cerkwi na Kołoży, miejsc związanych z E. Orzeszkowa, bunkrów linii Mołotowa, zespołu pałacowo-parkowego Wołłowiczów w Świacku. Obiekty te (głównie militarne, religijne, kulturowo-historyczne, przyrodnicze) stanowią wspólne dziedzictwo Rzeczypospolitej i są celem sentymentalnych podróży zwłaszcza Polaków i Litwinów (Otwierając białoruskie pogranicze..., 2018). Możliwość bezwizowego przemieszczenia się przez obszary zachodniej Białorusi umożliwia także zwiedzenie trzech z czterech białoruskich obiektów z listy światowego dziedzictwa ludzkości UNESCO: Południka Struvego, zamku w Mirze i Puszczy Białowieskiej, oraz innych pomników kulturowo-historycznych w Brześciu, Lidzie i Nowogródku.

W efekcie otwarcia granic pojawiło się dużo możliwości wjazdu i wyjazdu do białoruskiej strefy bezwizowej (w tym przestrzeni turystycznej Kanału Augustowskiego). Łącznie istnieje 14 przejść granicznych i wiele sposobów ich przekraczania: kajakiem, rowerem, pieszo, samochodem, autokarem, pociagiem i samolotem. Obecnie turyści mogą wjechać do Białorusi na okres do 15 dób przez przejście Rudawka-Lesnaja, zwiedzić Grodno, wyjechać zaś - przez przejścia graniczne Terespol-Brześć i Białowieża-Piererów bądź spłynąć kajakiem na Litwę przez Privalka-Svendubre. W przypadku przejścia Rudawka-Lesnaja łączenie niektórych możliwości podróżowania jest jednak dyskusyjne, gdyż nie ma np. stałych lotów z Polski do Grodna lub Brześcia. Istnieją też inne problemy w organizacji wyjazdów: trudności z wypożyczeniem/pozostawieniem kajaków czy rowerów po drugiej stronie granicy, ograniczenia dostępności transportu publicznego (autobusów, pociągów), a także możliwości fizyczne turystów.

\section{TRANSGRANICZNOŚĆ I PRZYGOTOWANIE PRZESTRZENI TURYSTYCZNEJ}

Ważnym elementem przestrzeni turystycznej jest również zagadnienie delimitacji obszaru (sub)regionu funkcjonalnego współpracy transgranicznej, określany przez badaczy jako Puszcza Augustowska (Suliga, 1996), obszar (region) białostocko-grodzieński (Eberhardt, 1996) lub obszar Puszczy Augustowsko-Grodzieńskiej (Roman, Sawośko, Żendzian, Niesteruk, 2018) (rys. 1). Istotne pytanie $\mathrm{w}$ badaniach nad transgranicznym ruchem turystycznym stanowi to, czy brany jest pod uwage jedynie bezpośredni obszar Puszczy Augustowskiej, czy też szersza przestrzeń turystyczna wraz z Białymstokiem, Grodnem, a nawet Druskiennikami. Od 1997 r. obszar Kanału Augustowskiego wszedł w skład Euroregionu Niemen i objął przygraniczne województwo podlaskie, obwód grodzieński (w całości) oraz niektóre gminy Litwy i rosyjskiego obwodu kaliningradzkiego (Kowalewska, Słoma, 2015). Peryferyjne, transgraniczne euroregiony: Niemen, Puszcza Białowieska (Polska, Białoruś) i Bug (Polska, Białoruś, Ukraina), tworzą ważne obszary „zielonej turystyki”, a także turystyki kulturowej i nostalgicznej (Marin, 2017).

Ponadto od 2007 r. Białoruś jest wśród sześciu państw objętych Parrtnerstwem Wschodnim jako części 


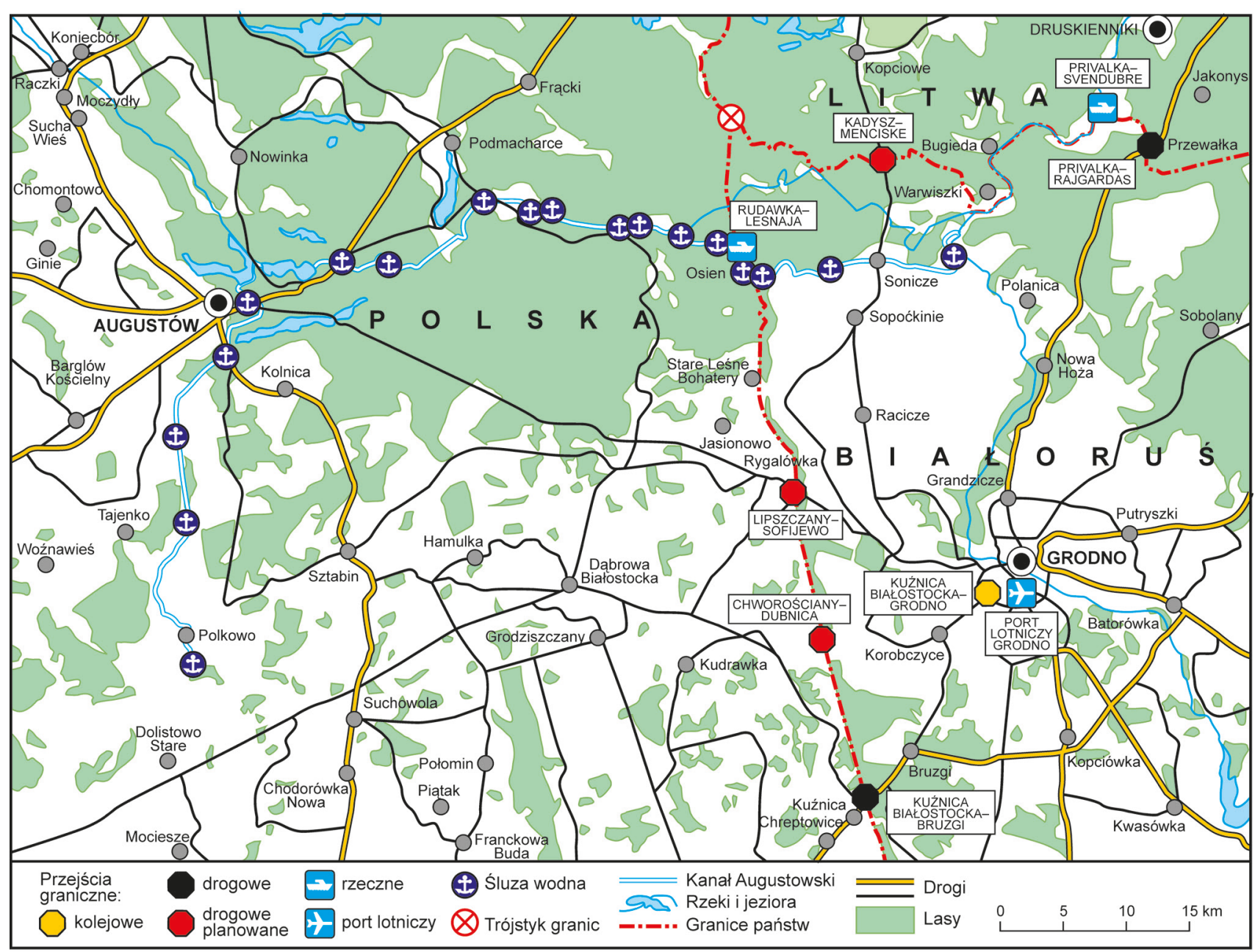

Rysunek 1. Lokalizacja Kanału Augustowskiego Źródło: opracowanie własne

Instrumentu Europejskiego Sąsiedztwa i Partnerstwa w ramach Programu Współpracy Transgranicznej „Polska-Białoruś-Ukraina” oraz „Łotwa-Litwa-Białoruś". Te programy współpracy są skierowane na najmniej upolitycznione kwestie, takie jak: ochrona środowiska, turystyka, bezpieczeństwo transgraniczne, a także transgraniczne kontakty lokalnych ośrodków społecznych i gospodarczych. Niemniej jednak z powodu geograficznej lokalizacji zarówno dla Ukrainy i Łotwy, jak i w mniejszym stopniu dla Litwy kwestie dotyczące Kanału Augustowskiego są drugorzędne.

Rolę narzędzia sprzyjającego intensyfikacji przepływów turystycznych mógłby pełnić mały ruch graniczny (MRG), rozwijany na podstawie trzech odrębnych umów, które Białoruś zawarła w 2010 r. z Polska, Litwą oraz Łotwą. Jednak jedynie z Łotwą porozumienie to weszło w życie w 2012 r. Władze białoruskie, głównie z przyczyn gospodarczych, odmówiły Polsce oraz Litwie uruchomienia umowy o MRG, obawiając się, iż ok. 1,5 mln Białorusinów będzie miało możliwość robienia tanich zakupów w sąsiednich krajach (Yeliseyeu, 2017).

\section{CZYNNIKI WPŁYWAJĄCE NA LOKALNY RUCH TURYSTYCZNY}

Do najważniejszych wydarzeń, które odcisnęły wyraźne piętno na przestrzeni turystycznej Kanału Augustowskiego, należy zaliczyć otwarcie w 2005 r. polsko-białoruskiego rzecznego przejścia granicznego RudawkaLesnaja, zlokalizowanego przy śluzie Kurzyniec (fot. 1). W latach 2004-2006 przeprowadzono generalny remont

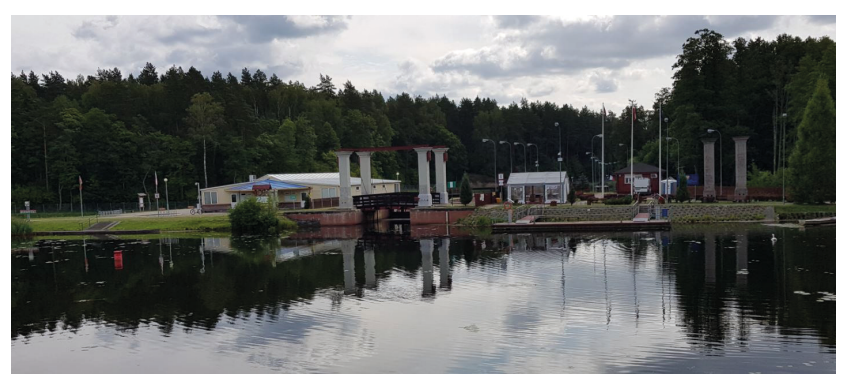

Fotografia 1. Śluza Kurzyniec nad Kanałem Augustowskim na polsko-białoruskim przejściu granicznym Rudawka-Lesnaja Źródło: Marek Więckowski (lipiec 2019) 
śluz, jazów i zlewni zarówno po białoruskiej, jak i po polskiej stronie. Likwidacja zakola, zwiększona erozja oraz obniżenie poziomu wody (do ok. 1,4 m) zmienily położenie koryta Niemna, co przyczyniło się do powstania czwartej (dodatkowej) komory śluzy Niemnowo (Ber, Graniczny, Kowalski, Marks, Urban, 2007).

Kolejnym bodźcem do rozwoju lokalnego ruchu turystycznego stało się wprowadzenie od 10 października 2016 r. na Białorusi bezwizowego reżimu wjazdu do parku turystyczno-rekreacyjnego Kanału Augustowskiego. Ta decyzja cechuje się stopniowym zwiększaniem rozmiaru strefy bezwizowej, przestrzeni turystycznej Kanału Augustowskiego oraz liczby dostępnych przejść granicznych dla bezwizowego ruchu, a także wydłużeniem czasu pobytu. Kolejne zwiększenia rozmiaru strefy oraz liczby przejść dla bezwizowego ruchu na pograniczu polsko-białoruskim oraz litewsko-białoruskim miały miejsce 1 stycznia 2018 r. i 10 listopada 2019 r. (Bobowska, 2018; Więckowski, Cyargeenka, 2019) (tab. 1).

Warto podkreślić korzyści dla regionu Kanału Augustowskiego, jakie przyniosło wykorzystanie funduszy europejskich na rozbudowę transgranicznej infrastruktury turystycznej. Są to głównie naprawy lub budowa sieci nowych dróg. Niestety w niektórych z tych działań nie uwzględniono kwestii spójności transgranicznej przestrzeni turystycznej. Zazwyczaj modernizacje lokalnych dróg białoruskich, polskich bądź litewskich są przeprowadzane oddzielnie, bez uwzględnienia sytuacji transportowej całości. Są również przypadki budowy tzw. dróg donikąd, które prowadzą w kierunku granicy, ale nie istnieją tam przejścia graniczne. Przykładowo zbudowana w 2014 r. autostrada H-6049 Raticzi-Polnyje Bogatyri na Białorusi oraz droga wojewódzkiej nr 664 w Polsce, która miała połączyć białoruski obszar Kanału Augustowskiego i Grodna z Augustowem, nie pełnią swojego zadania, ponieważ nadal nie powstało planowane drogowe przejście graniczne Lipszczany-Sofijewo. Podobna sytuacja ma miejsce na niefunkcjonującym przejściu Kadysz-Menciske na granicy białorusko-litewskiej.

Istotną barierą procesu dynamizacji ruchu granicznego na poziomie lokalnym jest dylemat: ochrona środowiska czy rozwój infrastruktury. Z jednej strony transgraniczna Puszcza Augustowska ma wiele obszarów ochrony przyrody, gdzie rozbudowa infrastruktury (w tym turystycznej) jest zabroniona lub znacznie ograniczona (np. konflikt wokół budowy obwodnicy Augustowa w latach 2007-2009). Z drugiej strony rozwój infrastruktury na obszarze Kanału Augutowskiego w postaci budowy dróg, powiązań transportowych, ścieżek rowerowych oraz konnych, transgranicznych szlaków turystycznych, tras do żeglugi śródlądowej, wież widokowych, lokalnych turystycznych przejść itd. mógłby spowodować dalsze zwiększenie ruchu turystycznego (Więckowski, 2010a).

\section{ZMIANY RUCHU TURYSTYCZNEGO NA PRZYKŁADZIE PRZEJŚCIA GRANICZNEGO RUDAWKA-LESNAJA}

Analiza ruchu osobowego na przejściu granicznym Rudawka-Lesnaja prowadzi do wyodrębnienia trzech okresów jego funkcjonowania (rys. 2). Pierwszy stanowią lata 2005-2016, kiedy ruch charakteryzował się małą intensywnością i wyraźną dysproporcją między liczbą osób wyjeżdżających a wjeżdżających oraz ich obywatelstwem. W pierwszych latach po otwarciu przejścia zdecydowanie więcej było wyjeżdżających z Polski niż przyjeżdżających. W 2005 r. wyjechało na Białoruś 16 razy więcej osób niż z niej wjechało do Polski, ale w 2016 r. już tylko 1,6 razy więcej. Skala tego ruchu była jednak minimalna. Najwięcej osób (275) wyjechało z Polski w 2010 r., najwięcej (175) zaś przyjechało do tego kraju w 2012 r. Minimum (po 10 osób) przypada na rok 2005 (przyjazdy) i 2006 (przyjazdy i wyjazdy).

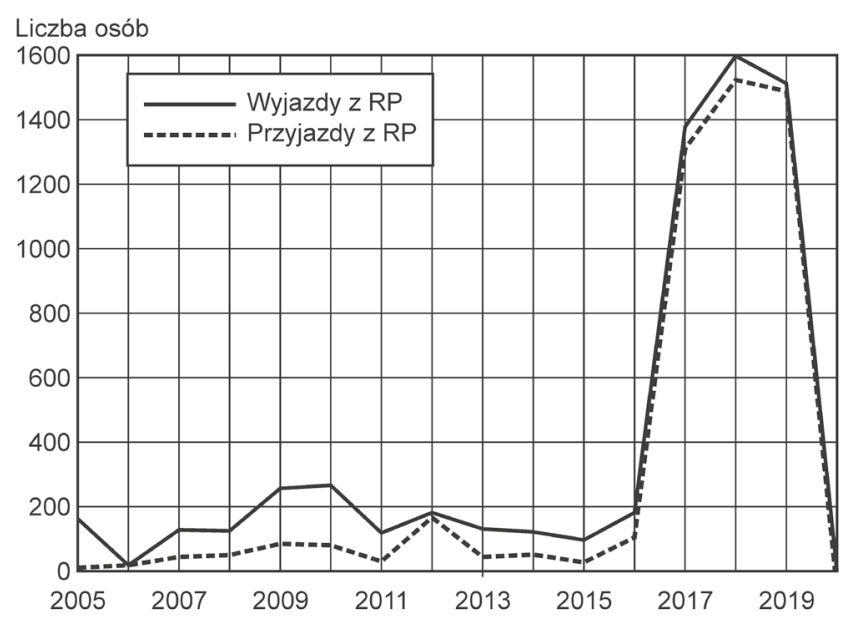

Rysunek 2. Liczba osób przekraczających polsko-białoruską granicę przez przejście Rudawka-Lesnaja w latach 2005-2020

Źródło: opracowanie własne na podstawie danych Straży Granicznej (SG)

Drugi okres obejmuje lata 2017-2019 i charakteryzuje się nagłym wzrostem ruchu osobowego. W 2017 r. liczba osób wyjeżdżających z Polski zwiększyła się ponad 8 razy, a przyjeżdżających do Polski wzrosła ponad 12 razy w porównaniu z 2016 r. Maksymalny ruch odnotowano w 2018 r., kiedy granicę w kierunku Białorusi przekroczyło 1615 osób, natomiast w kierunku Polski 1533 osoby. Głównymi przyczynami intensyfikacji ruchu turystycznego było wprowadzenie bezwizowego wjazdu do przygranicznych obszarów na Białorusi (zwłaszcza Kanału Augustowskiego i Grodna) oraz dopuszczenie możliwości przekraczania granicy na rowerze bądź pieszo. Konsekwencją decyzji polityczno-administracyjnych było przedłużenie polskiego Wschodniego Szlaku Rowerowego „Green Velo" 


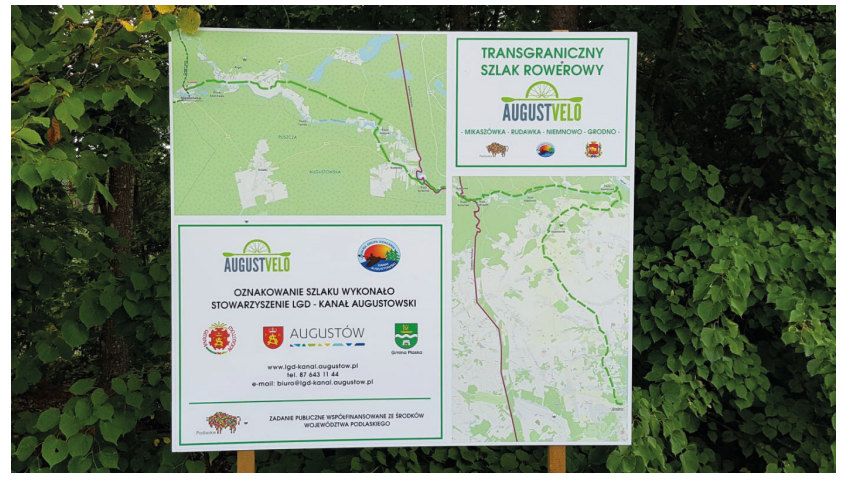

Fotografia 2. Tablica informacyjna z mapą transgranicznego szlaku rowerowego „August Velo" (,Green Velo") - Mikaszówka-Rudawka-Niemnowo-Grodno Źródło: Marek Więckowski (lipiec 2019)

na stronę białoruską pod nazwą Transgraniczny Szlak Rowerowy „August Velo" (Tourist pass port, 2018) (fot. 2).

W 2019 r. nastąpiło nieznaczne zmniejszenie ruchu granicznego. Osoby, które były najbardziej zainteresowane tą ofertą turystyczną (kajakarze, rowerzyści, miłośnicy turystyki sentymentalnej itd.), już z niej skorzystały i w najbliższym czasie nie planują ponownego wyjazdu.

Ostatni okres zaczął się w 2020 r., kiedy z powodu pandemii koronawirusa od końca marca na granicy polsko-białoruskiej dla ruchu osobowego pozostały otwarte jedynie trzy drogowe przejścia graniczne (TerespolBrześć, Kuźnica Białostocka-Bruzgi, BobrownikiBierestowica). Przejście Rudawka-Lesnaja zostało zamknięte, dlatego ruch graniczny w 2020 r. w ogóle się tu nie odbywat.

Analizując dynamikę ruchu granicznego pod kątem sezonowości, trzeba podkreślić, że to przejście z założenia ma okresowy tryb funkcjonowania - jest otwarte od końca kwietnia bądź początku maja do końca września lub początku października (w godzinach dziennych). Dodatkowo w latach 2005-2016 sposób przekraczania granicy można opisać jako „częściowo na zamówienie”. Ponieważ przedstawiciele służby celnej nie zawsze znajdowali się na miejscu, należało zgłosić wycieczkę co najmniej dzień przed spływem, aby nie czekać kilka godzin na odprawę. Utrudnienia z odprawą wynikały również z tego, że intensywność ruchu była bardzo mała. Inną przeszkodą były przeprowadzane w latach 2005-2007 prace remontowe Kanału Augustowskiego. Z informacji Staży Granicznej wynika, że bywały dni, a nawet i miesiące, kiedy nie odbywał się ruch graniczny. Dane z lat 2017-2019 dowodzą jednak jednoznacznie, że największe natężenie ruchu granicznego przypada na lipiec.

Ruch graniczny na przejściu Rudawka-Lesnaja jest zdominowany przez Polaków (rys. 3), zarówno pod względem wyjazdów, jak i przyjazdów. Wyjątkami są lata 2010 i 2017, w których więcej cudzoziemców przyjechało do Polski (rys. 4). Niestety brak jest

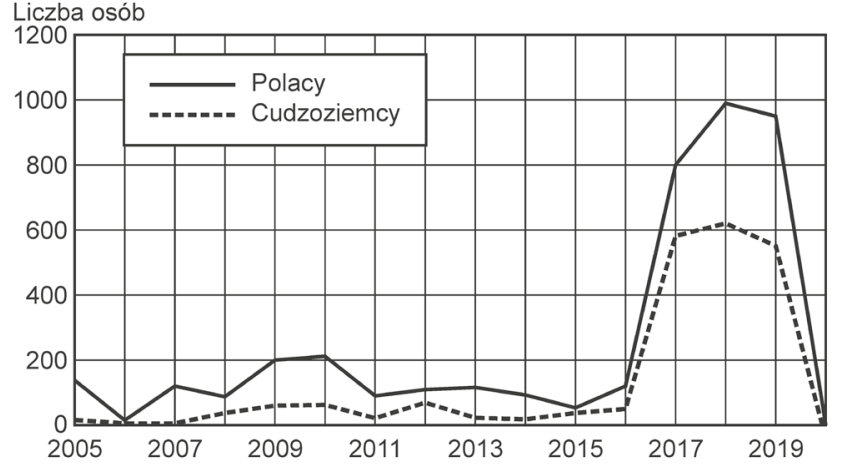

Rysunek 3. Liczba Polaków oraz cudzoziemców wyjeżdżających z Polski przez przejście graniczne Rudawka-Lesnaja w latach 2005-2020

Źródło: opracowanie własne na podstawie danych SG

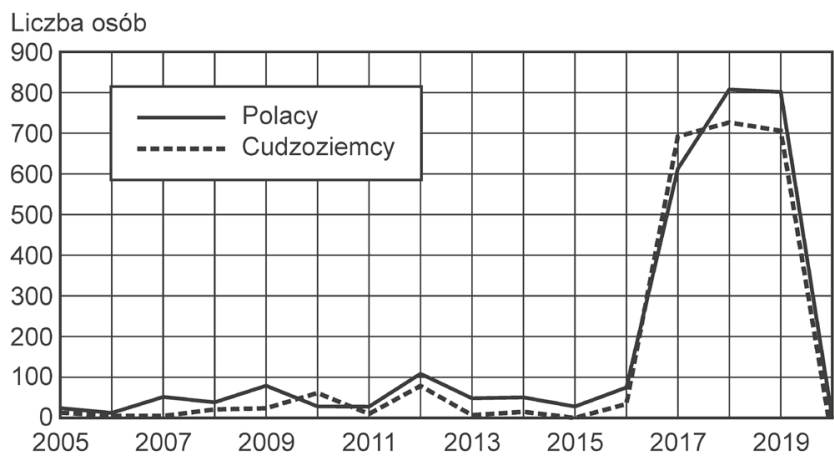

Rysunek 4. Liczba Polaków

oraz cudzoziemców przyjeżdżających do Polski przejście graniczne Rudawka-Lesnaja w latach 2005-2020 Źródło: opracowanie własne na podstawie danych SG

szczegółowych informacji o obywatelstwie cudzoziemców z lat 2005-2010 oraz za 2014 r. Dane Straży Granicznej z lat 2011-2013 i 2015-2019 wskazują na znaczną przewagę Białorusinów - ok. 80-90\%. Wśród obywateli innych państw przeważają Litwini, Rosjanie oraz Niemcy. W 2019 r. udział Polaków wśród osób przyjeżdżających do Polski wynosił 53\%, Białorusinów - 37\%, Litwinów $-3 \%$, Rosjan -3\%, Niemców - $2 \%$, obywateli innych krajów - $2 \%$. Wśród osób wyjeżdżających z Polski rozkład procentowy przedstawiał się następująco: Polacy $-63 \%$, Białorusini $-32 \%$, Litwini $-2 \%$, Rosjanie $-1 \%$, Niemcy $-1 \%$, inni - $1 \%$ (tab. 2). Wyraźnie widać, że duży wpływ na strukturę pochodzenia przekraczających granicę ma czynnik geograficzny. Większość osób pochodzi z państw ościennych: Białorusi, Polski, Litwy, Niemiec, Rosji, chociaż są sporadyczne przypadki podróżnych pochodzących z odległych krajów, takich jak: Wielka Brytania, Hiszpania, USA, Australia, Chiny.

Warto również zwrócić uwagę na różnicę liczby osób tej samej narodowości wjeżdżających i wyjeżdżających, zwłaszcza wśród Polaków oraz Białorusinów. W 2019 r. wyjechało z Polski prawie 150 Polaków $(1 / 5)$ więcej, niż przyjechało, jednocześnie wyjechało z Polski 
Tabela 2. Liczba osób przekraczających granicę przez przejście Rudawka-Lesnaja w latach 2017-2019 według stałego miejsca zamieszkania, rodzaju ruchu oraz kierunku (wyjazdy z Polski lub przyjazdy do Polski)

\begin{tabular}{|c|c|c|c|c|c|c|c|c|c|}
\hline Rok & Kierunek & Rodzaj przejścia & Polska & Białoruś & Litwa & Niemcy & Rosja & $\begin{array}{c}\text { Inne } \\
\text { państwa }\end{array}$ & Razem \\
\hline \multirow{6}{*}{2017} & \multirow{3}{*}{ wyjazdy } & drogowe & 455 & 453 & 6 & 0 & 5 & 18 & 937 \\
\hline & & rzeczne & 343 & 54 & 28 & 14 & 0 & 8 & 447 \\
\hline & & razem & 798 & 507 & 34 & 14 & 5 & 26 & 1384 \\
\hline & \multirow{3}{*}{ przyjazdy } & drogowe & 416 & 450 & 9 & 2 & 10 & 19 & 906 \\
\hline & & rzeczne & 203 & 177 & 1 & 8 & 1 & 11 & 401 \\
\hline & & razem & 619 & 627 & 10 & 10 & 11 & 30 & 1307 \\
\hline \multirow{6}{*}{2018} & \multirow{3}{*}{ wyjazdy } & drogowe & 619 & 407 & 3 & 12 & 14 & 6 & 1061 \\
\hline & & rzeczne & 374 & 119 & 41 & 8 & 3 & 9 & 554 \\
\hline & & razem & 993 & 526 & 44 & 20 & 17 & 15 & 1615 \\
\hline & \multirow{3}{*}{ przyjazdy } & drogowe & 608 & 379 & 2 & 4 & 14 & 10 & 1017 \\
\hline & & rzeczne & 204 & 290 & 9 & 0 & 7 & 8 & 518 \\
\hline & & razem & 812 & 669 & 11 & 4 & 21 & 18 & 1535 \\
\hline \multirow{6}{*}{2019} & \multirow{3}{*}{ wyjazdy } & drogowe & 501 & 438 & 2 & 21 & 16 & 8 & 986 \\
\hline & & rzeczne & 452 & 38 & 14 & 4 & 3 & 11 & 522 \\
\hline & & razem & 953 & 476 & 16 & 25 & 19 & 19 & 1508 \\
\hline & \multirow{3}{*}{ przyjazdy } & drogowe & 502 & 471 & 31 & 20 & 39 & 29 & 1092 \\
\hline & & rzeczne & 298 & 87 & 14 & 2 & 10 & 2 & 413 \\
\hline & & razem & 800 & 558 & 45 & 22 & 49 & 31 & 1505 \\
\hline
\end{tabular}

Źródło: opracowanie własne na podstawie danych SG.

80 Białorusinów (prawie ${ }^{1 / 5}$ ) mniej, niż przyjechało. Może to być konsenwencją powrotu do kraju przez inne przejście graniczne lub dłuższego pobytu w odwiedzanym kraju.

Interesujących wyników dostarcza też analiza ruchu granicznego z uwagi na tryb przekraczania granicy (drogowy, wodny) i obywatelstwo podróżujących. Ponieważ przekraczanie granicy pieszo lub na rowerze zaczęło być możliwe de facto od początku maja 2017 r., dostępne są jedynie dane z lat 2017-2019 (tab. 2). Wynika z nich, że:

- więcej Polaków (ok. 55-60\%) wyjeżdża z Polski środkiem pływającym, niż wraca (ok. 35-40\%), w przeciwieństwie do Białorusinów, których wyjeżdża z Polski procentowo mniej (ok. 30\%), niż przyjeżdża (ok. 70\%); - w trybie drogowym ta różnica wynosi zarówno dla Polaków, jak i Białorusinów jedynie 1-2\%.

Należy podkreślić, że tylko 10-20\% Białorusinów wyjeżdżających z Polski wybiera tryb wodny, a odsetek przyjeżdżających znacznie wahał się przez te trzy lata (28\% w 2017 r., 43\% w 2018 r. i 16\% w 2019 r.). Procentowy udział Polaków korzystających z możliwości rzecznego przekraczania granicy jest znacząco większy oraz bardziej zrównoważony - 38-47\% w odniesieniu do wyjazdów z Polski oraz $25-37 \%$ w stosunku do przyjazdów do Polski.

Czynnikami wpływającymi na dysproporcje między ruchem wodnym i drogowym są:
- zdecydowanie lepiej rozwinięta infrastruktura turystyczna w Polsce - samodzielna, wielokrotnie większa baza sportów wodnych z łatwiejszymi warunkami wypożyczania środków pływających;

- znacznie uboższa białoruska oferta wypożyczenia kajaków, rowerów wodnych itd., która jest dostępna generalnie tylko wokół przystani przy śluzie Dąbrówka;

- brak możliwości przekraczania granicy państwowej środkiem transportu wypożyczonym na Białorusi (według danych zebranych przed wyjazdem terenowym od 10 białoruskich firm);

- łatwiejszy sposób spływu kajakiem po Kanale Augustowskim z prądem, z Polski do Białorusi oraz ewentualnie dalej Niemnem na Litwę, niż płynięcie pod prąd;

- obecność innych przejść granicznych, przez które osoba może wjechać na obszar Kanału Augustowskiego lub opuścić go.

\section{PODSUMOWANIE}

Reasumując przeprowadzone badania, można stwierdzić, że potwierdzono postawioną hipotezę badawczą. Dzięki złagodzeniu reżimu granicznego na Białorusi oraz stopniowemu poszerzeniu stref bezwizowych 
w latach 2015-2016 znacznie wzrósł zagraniczny ruch turystyczny, zarówno na poziomie krajowym¹, jak i lokalnym - na obszarze Kanału Augustowskiego. Na intensyfikację ruchu przez rzeczne przejście RudawkaLesnaja wpływ miało też wprowadzenie w 2017 r. drogowego trybu przekraczania granicy (pieszo bądź na rowerze). Lata 2017-2019 były okresem najbardziej ożywionego ruchu turystycznego na tym przejściu, zwłaszcza obywateli państw Euroregionu Niemen: Polski, Białorusi, Litwy oraz Rosji, z wyraźną dominacją pierwszych dwóch (ok. 90\%). Tryb wodny preferowali raczej Polacy, natomiast drogowy - Białorusini. Stwierdzono duże dysproporcje liczby turystów przyjeżdżających oraz wyjeżdżających, w zależności od kierunku ruchu, kraju pochodzenia, trybu przekraczania granicy i sezonowości. Były dni, a nawet tygodnie, kiedy nie odnotowano jakiegokolwiek ruchu granicznego. Jak również sytuacje, gdy danego dnia granicę w jednym kierunku przekraczało kajakiem, na rowerze lub pieszo kilkudziesięciu obywateli Białorusi, Polski oraz Litwy, zaś w odwrotnym - nikt (nawet w ciągu całego tygodnia).

Otwarcie przejścia Rudawka-Lesnaja na Kanale Augustowskim dla ruchu osobowego wraz z dostępem do licznych atrakcji (wodnych, przyrodniczych, kulturowo-historycznych) samo w sobie może stanowić podstawę do intensywnego rozwoju turystyki. Największy potencjał dla transgranicznej turystyki ma sam Kanał Augustowski jako oś współpracy. Najbardziej zaawansowanym produktem jest obecnie organizacja wypraw turystyki aktywnej i specjalistycznej na Kanale Augustowskim, rozumianym jako produkt turystyczny - szlak (II poziom integracji według Stasiaka i Włodarczyka, 2008). Jest jednak jeszcze za wcześnie, by mówić o ukształtowaniu transgranicznego obszaru turystycznego. Pozytywne tendencje z ostatnich kilkunastu lat mogą być zahamowane przez różne negatywne procesy i zjawiska. Od 2020 r. na ruch turystyczny na Kanale Augustowskim wpływają przede wszystkim kolejne lockdowny, ogłaszane w wyniku rozprzestrzeniania się epidemii koronawirusa oraz skomplikowana sytuacja polityczna na Białorusi, która spowodowała pogorszenie się zarówno polsko-białoruskich, jak i białorusko-europejskich stosunków, nawet na poziomie regionalnej i lokalnej współpracy.

\section{PRZYPIS}

${ }^{1}$ W 2014 r. Białoruś odwiedziło 1,7 tys. zorganizowanych turystów oraz odwiedzających jednodniowych z Polski, w 2015 r. - ok. 6 tys., w 2016 r. - ok. 8 tys., w 2017 r. - 22,7 tys., a w 2018 r. - 46,3 tys. (Więckowski, Cyargeenka, 2019). Liczba turystów oraz odwiedzających jednodniowych z Litwy również wzrosła z ok. 2 tys. w 2014 r. do 59,5 tys. w 2018 r. Udział Litwinów w ruchu przez przejście graniczne Rudawka-Lesnaja od lat pozostaje jednak na tym samym poziomie - 1-3\%. Przyczynami takiego stanu rzeczy mogą być: lokalizacja przejścia na polsko-białoruskim pograniczu, trudności w płynięciu kajakiem pod prąd z Litwy (Niemnem potem Kanał Augustowski), a także inny niż turystyka cel wizyt Litwinów na Białorusi (zakupy).

\section{BIBLIOGRAFIA}

Around Augustów Canal (2018). Białystok: Augustvelo.

Batura, W. (tekst), Mikos, M., Szlaszyński, J. (współpr.) (2005). Kanał Augustowski: wspólne dziedzictwo i przyszłość. Augustów: Zarząd Powiatu.

Ber, A., Graniczny, M., Kowalski, Z., Marks, L., Urban, H. (2007). Kanał Augustowski jako przykład dziedzictwa historycznego, technicznego i przyrodniczego [The Augustów Canal as an example of historical, technical and natural heritage]. Przeglad Geologiczny, 55 (9), 765-769.

Bobowska, M. (2018). Turystyka bezwizowa pomiędzy Polską a Białorusią z punktu widzenia studentów z miasta Białegostoku i okolic - korzyści oraz szanse. W: S. Sialverstava, A. Roman, J. Zuzda (red.), Promocja turystyki na pograniczu polsko-białoruskim (s. 189-200). Białystok: Wydawnictwo Niepublicznej Placówki Doskonalenia Nauczycieli „Edukacja, Wychowanie i Bezpieczeństwo" przy Towarzystwie Zapobiegania Tonięciom i Ratowania Tonących w Białymstoku.

Bogusz, T., Sialverstava, S. (2018). Wielokulturowość polsko-białoruskiego pogranicza: aspekt turystyczny. W: S. Sialverstava, A. Roman, J. Zuzda (red.), Promocja turystyki na pograniczu polsko-białoruskim (s. 69-78). Białystok: Wydawnictwo Niepublicznej Placówki Doskonalenia Nauczycieli „Edukacja, Wychowanie i Bezpieczeństwo" przy Towarzystwie Zapobiegania Tonięciom i Ratowania Tonących w Białymstoku.

Cudowski, A., Górniak, A. (2008). Przyrodnicze uwarunkowania funkcjonowania Kanału Augustowskiego i jego hydrochemia. W: E. Jekatierynczuk-Rudczyk, M. Stepaniuk (red.), Rozwój obszarów przyrodniczo cennych (s. 165-176). Białystok: Oddział Białostocki Polskiego Towarzystwa Geograficznego.

Cyargeenka, A., Więckowski, M. (2020). Expanding transboundary tourist space - The growing significance of the Augustów Canal. Baltic Journal of Health and Physical Activity, 12 (Special Issue 1), 130-138. https://doi.org/10.29359/BJHPA.12.Spec.Iss1.15

Eberhardt, P. (1996). Propozycja wydzielenia regionów współpracy na wschodnim pograniczu Polski. W: A. Miszczuk, R. Wiśniewski (red.), Informacyjno-infrastrukturalne uwarunkowania wspótpracy transgranicznej. Vol. 2 (s. 85-88). Lublin: Norbertinum.

Górewicz, J. (1974). Opowieść o Kanale Augustowskim. Warszawa: Wydawnictwo "Sport i turystyka".

Górewicz, J., Orłowski, B. (1973). Kanał Augustowski: 150 lat. Augustów: Towarzystwo Miłośników Ziemi Augustowskiej.

Kałuski, S. (2016). Trójstyki granic politycznych. Zróżnicowanie cech i funkcji. Czasopismo Geograficzne, 87 (2), 101-115.

Kolosov, V., Więckowski, M. (2018), Border changes in Central and Eastern Europe: An introduction. Geographia Polonica, 91 (1), 5-16. https://doi.org/10.7163/GPol.0106

Kopciała, J. (red.) (2000a). Kanał Augustowski: od Biebrzy do Niemna. Augustów-Suwałki: Wydawnictwo Hańcza.

Kopciała, J. (red.) (2000b). Kanał Augustowski: Szlak wodny Euroregionu Niemen. Augustów-Suwałki: Urząd Miejski, „Hańcza”.

Kowalczyk, A. (2014). Fenomenologia przestrzeni turystycznej. Turyzm/Tourism, 24 (1), 9-15. https://doi.org/10.2478/ tour-2014-0001 
Kowalewska, P., Słoma, A. (2015). Euroregion Niemen jako przykład współpracy transgranicznej. W: J. Grabowiecki (red.) Wspótpraca transgraniczna na wschodnim pograniczu Polski (s. 145-153). Białystok: Wydawnictwo Uniwersytetu w Białymstoku.

Kudžmaitè, G. (2019). Before, during and after crossing the border: Narrating the 'visa-free Grodno'. Visual Studies. 34 (2), 148-163. https://doi.org/10.1080/1472586X.2019.1654910

Kul-Sialverstava, S. (2014). Pamięć historyczna mieszkańców pogranicza białorusko-polskiego. W: K. Snarski, A. Żulpa (red.), W krainie wielu tradycji. Badania etnograficzne na pograniczu polsko-litewsko-białoruskim w XX i początkach XXI wieku (s. 120-136). Suwałki: Wydawnictwo Muzeum Okręgowego w Suwałkach. Lenart, W. (2008). Zakres możliwej transgranicznej współpracy Białorusi, Litwy, Polski, Rosji i Ukrainy w dziedzinie gospodarki przestrzennej, zrównoważonego rozwoju oraz promocji regionalnej z uwzględnieniem założeń zielonych płuc Europy i ze szczególnym uwzględnieniem Kanału Augustowskiego. W: L. Witold, A. Zelenkov, Kanał Augustowski i wspótczesna ekoturystyka (s. 277-295 ). Pułtusk-Mińsk-Grodno: Akademia Humanistyczna im. Aleksandra Gieysztora w Pułtusku.

Marin, A. (2011). From breach to bridge: The Augustów Canal, an ecotourism destination across the EU's border with Belarus. Articulo. Pobrane z: https://journals.openedition.org/articulo/1705 (10.06.2020). https://doi.org/10.4000/articulo.1705

Marin, A. (2017). Of barriers, breaches and bridges. Cross-border ecotourism and the prospect of horizontal governance acting as a bridge in Belarus-EU neighbourhood relations. W: I. Liikanen, J.W. Scott, T. Sotkasiira (red.), The EU's Eastern neighbourhood. Migration, borders and regional stability (s. 115133). Londyn-Nowy Jork: Routledge.

Otwierajac białoruskie pogranicze. Kanał Augustowski i Grodno (2018). Grodno: Centrum Informacji turystycznej w Grodnie.

Pogranicze białoruskie do wypoczynku i podróży. Kanał Augustowski $i$ Grodno (2018). Grodno: Centrum Informacji turystycznej w Grodnie.

Pozlevich, T. (red.) (2016). Augustovski Channel/Kanał Augustowski. Mińsk: PrestigeIzdatReklama.

Roman, A., Sawośko, K., Żendzian, J., Niesteruk, P. (2018). Motywy podróżowania na pograniczu polsko-białoruskim. W: S. Sialverstava, A. Roman, J. Zuzda (red.), Promocja turystyki na pograniczu polsko-białoruskim (s. 171-188). Białystok: Wydawnictwo Niepublicznej Placówki Doskonalenia Nauczycieli „Edukacja, Wychowanie i Bezpieczeństwo" przy Towarzystwie Zapobiegania Tonięciom i Ratowania Tonących w Białymstoku.

Romanowa, O.S., Szirokowa, V.A., Ozierowa, N.A., Czesnow, V.M., Sobisiewicz, A.V. (2018). Augustow Canal as the monument of hydraulics and the objects of heritage tourism. Acta Geographica Silesiana, 12/3 (31), 37-44.

Rutkowski, M. (2017). Water canal system in projects, activities and reports of Polish authorities in the 1830s-1860s. Scientific Journal of Silesian University of Technology. Series Transport, 94, 211-227. https://doi.org/10.20858/sjsutst.2017.94.19
Sialverstava, S., Bogusz, T. (2018). Szlaki turystyczne w województwie podlaskim. W: S. Sialverstava, A. Roman, J. Zuzda (red.), Promocja turystyki na pograniczu polsko-biatoruskim (s. 121-134). Białystok: Wydawnictwo Niepublicznej Placówki Doskonalenia Nauczycieli „Edukacja, Wychowanie i Bezpieczeństwo" przy Towarzystwie Zapobiegania Tonięciom i Ratowania Tonących w Białymstoku.

Sialverstava, S., Bogusz, T., Roman, M. (2018). Tourism development in the Belarusian part of the Augustow Canal. Turystyka $i$ Rozwój Regionalny, 9, 63-70. https://doi.org/10.22630/TIRR.2018.9.7

Stasiak, A., Włodarczyk, B. (2008). Transgraniczne produkty turystyczne. W: Transkordonne spivorobitnictvo âk faktor aktivizacii êvroìntegracìnnich procesìv, Materiali XVII Mižnarodnoï naukovo-praktičnoï konferenciï (s. 336-338). Černìvì 6-7 travnâ 2008 roku.

Stoffelen, A., Ioannides, D., Vanneste D. (2017). Obstacles to achieving cross-border tourism governance: A multi-scalar approach focusing on the German-Czech borderlands. Annals of Tourism Research, 64, 126-138. https://doi.org/10.1016/j. annals.2017.03.003

Suliga, J. (1996). Polsko-białoruska współpraca przygraniczna w dziedzinie planowania przestrzennego. W: A. Miszczuk, R. Wiśniewski (red.), Informacyjno-infrastrukturalne uwarunkowania wspótpracy transgranicznej. Tom 2 (s. 89-92). Lublin: Norbertinum.

Tourist Passport (2018). Białystok: Augustvelo.

Więckowski, M. (2010a). Specific features of development of tourism within the areas neighbouring upon the Polish Eastern border, European Union external and internal borders - interactions and networks. Europa XXI, 20, 101-115. https://doi. org/10.7163/Eu21.2010.20.8

Więckowski, M. (2010b). Tourism development in the borderlands of Poland. Geographia Polonica, 83 (2), 67-81. https://doi. org/10.7163/GPol.2010.2.5

Więckowski, M. (2014). Przestrzeń turystyczna - próba nowego spojrzenia. Turyzm/Tourism, 24 (1), 17-24. https://doi.org/10.2478/ tour-2014-0002

Więckowski, M., Cyargeenka, A. (2019). Wpływ złagodzenia reżimu granicznego na Białorusi na wielkość ruchu turystycznego - wstęp do badań. Przeglą Geograficzny, 91 (4), 589-608. https://doi.org/10.7163/PrzG.2019.4.8

Włodarczyk, B. (2014). Przestrzeń w turystyce, turystyka w przestrzeni-o potrzebie podziałów i klasyfikacji. Turyzm/Tourism, 24 (1), 25-35. https://doi.org/10.2478/tour-2014-0003

Yeliseyeu, A. (2017). Die neue Visaregelung. Langsam und mit Einschränkungen öffnet sich Belarus Reisenden aus dem Westen. Belarus-Analysen, 32, 2-6. https://doi.org/10.31205/ BA.032.01

Zichner, H., Beurskens, K., Miggelbrink, J., Bruns, B. (2017). Vor, an und hinter der Grenzlinie - Praktiken von Kontrollierenden und Kontrollierten. W: J. Miggelbrink (red.), Grenze aushandeln: eine Untersuchung zur östlichen Schengengrenze 2007-2009 (s. 116-121). Leipzig: Leibniz-Institut für Länderkunde. 